\title{
Nanochelating based nanocomplex, GFc7, improves quality and quantity of human mesenchymal stem cells during in vitro expansion
}

\author{
Maryam Hafizi ${ }^{1,2}$, Atena Hajarizadeh ${ }^{1}$, Amir Atashi ${ }^{3}$ Somayeh Kalanaky², Saideh Fakharzadeh², Zahra Masoumi ${ }^{1}$,
} Mohammad Hassan Nazaran ${ }^{2^{*}}$ and Masoud Soleimani ${ }^{3^{*}}$

\begin{abstract}
Introduction: Human mesenchymal stem cells (hMSCs) have been approved for therapeutic applications. Despite the advances in this field, in vitro approaches are still required to improve the essential indices that would pave the way to a bright horizon for an efficient transplantation in the future. Nanotechnology could help to improve these approaches. Studies signified the important role of iron in stem cell metabolism and efficiency of copper chelation application for stem cell expansion
\end{abstract}

Methods: For the first time, based on novel Nanochelating technology, we design an iron containing copper chelator nano complex, GFC7 and examined on hMSCs during in vitro expansion. In this study, the hMSCs were isolated, characterized and expanded in vitro in two media (with or without GFc7). Then proliferation, cell viability, cell cycle analysis, surface markers, HLADR, pluripotency genes expression, homing and antioxidative defense at genes and protein expression were investigated. Also we analyzed the spontaneous differentiation and examined osteogenic and lipogenic differentiation.

Results: GFC7 affected the expression of key genes, improving both the stemness and fitness of the cells in a precise and balanced manner. We observed significant increases in cell proliferation, enhanced expression of pluripotency genes and homing markers, improved antioxidative defense, repression of genes involved in spontaneous differentiation and exposing the hMSCs to differentiation medium indicated that pretreatment with GFC7 increased the quality and rate of differentiation.

Conclusions: Thus, GFc7 appears to be a potential new supplement for cell culture medium for increasing the efficiency of transplantation.

Keywords: Expansion, GFc7, Human mesenchymal stem cells, Nanocomplex, Nanochelating technology

\section{Introduction}

Human mesenchymal stem cells (hMSCs), a subset of the multipotent non-hematopoietic stem cells found primarily within the bone marrow, have been extensively studied in recent years due to their potential for diverse

\footnotetext{
*Correspondence: mnazaran@nanochelatingtechnology.com;

soleim_m@modares.ac.ir

2Department of Research and Development, Sodour Ahrar Shargh Company, Tehran, Iran

${ }^{3}$ Department of Hematology, Faculty of Medical Sciences, Tarbiat Modares University, Tehran, Iran

Full list of author information is available at the end of the article
}

applications in regenerative medicine $[1,2]$. hMSCs have an innate self-renewal capability that is compatible with in vitro expansion systems, enabling maintenance and mass production that is comparable with other stem cells for downstream clinical applications. They can also differentiate into multiple cell types and lineages, including osteoblasts, cardiocytes, and neural cells. In addition, owing to their accessibility and ease of isolation from multiple sources, hMSCs may have a broader application spectrum because they can be readily used for auto-graft transplantation. The HLA-DR-negative nature of hMSCs 
increases the rate of successful transplantations, and their immunomodulatory features qualify them for treating numerous autoimmune diseases [3-6]. All of these features together have made hMSCs one of the best candidates for a multitude of cell therapy applications but despite the efficient performance of hMSCs and their important advantages, they did not achieve satisfactory effects in some investigations $[7,8]$ and the question as to what their effective influence is after transplantation remains unanswered [9-11].

The success rate of hMSCs cell therapy significantly decreases due to induced apoptosis in the transplanted cells during the first day of transplantation $[8,12]$. It is clear from the literature that this in vitro expansion phase causes dramatic changes in the hMSCs phenotype, which has considerable implications for the development of effective therapies [13].

Recently, to overcome the concomitant problems of the existing procedures, researchers have developed diverse new strategies for in vitro culture. Nanotechnologybased approaches have evolved to provide nanostructures for improving the quantity and fitness of stem cells for more successful in vivo transplantations [14]. Nanochelating technology is a modern field that has the capacity to design and synthetize nano structures via a self-assembly method [15]. In previous studies using this modern technology, Hep-c nano adjuvant and MSc1 nano-complex were synthetized. Hep-c improved cellular immune responses against hepatitis B vaccine [16]. MSc1 nanocomplex showed therapeutic behavior in an animal model of multiple sclerosis [17] and neuroprotective effects of three different sizes of nanochelating based nano complexes in $\mathrm{MPP}(+)$ induced neurotoxicity [5] were recently reported.

For the first time, based on novel nanochelating technology, we designed and synthesized an iron containing copper chelator nanocomplex (GFc7) via a self-assembly method.

The important role of iron in cell metabolism is clear. Iron is a key cofactor of vital enzymes that are involved in cell cycle promotion [18] and hMSCs proliferation [19], so GFc7 is loaded with iron. On the other hand, several studies reported positive outcomes of using copper chelators for expansion of cord blood hematopoietic stem cells in vitro [20] and in transplantation (phase I/II clinical trial) [19]. Also, an increase in the extracellular concentration of copper modulated the ability of hMSCs to spontaneously differentiate [20]. Based on these reports, GFc7 was designed in a way that has chelating properties with the dominant affinity for copper.

Available reports imply negative effects of oxidative stress on hMSCs functionality [21], expansion and differentiation. Oxidative stress has an important role in the initiation and progression of diseases such as cancer and autoimmune diseases; a huge number of hMSCs recipients have these diseases [22].

Therefore, in this study, we hypothesize that the competent GFc7 structure could increase the efficiency of hMSCs by maximizing antioxidative defense [23] (common cellular model using "H2O2" for evaluating the effect of GFc7), expression of pluripotency markers, cell expansion without spontaneous differentiation, and suitable homing by promoting differentiation potential.

\section{Materials and methods}

\section{Materials and instrumentation}

GFC7 nanocomplex was synthesized by Sodour Ahrar Shargh Company (Tehran, Iran). Minimum essential medium $(\alpha-\mathrm{MEM})$, penicillin $\mathrm{G}(100 \mathrm{U} / \mathrm{ml})$, streptomycin $(100 \mu \mathrm{g} / \mathrm{ml})$, GlutaMAX, nonessential amino acids, trypsin-EDTA $0.25 \%$, and phosphate-buffered solution (PBS) were purchased from Gibco (Gibco-Life Technologies, Carlsbad,CA, USA). Hydrogen peroxide $\left(\mathrm{H}_{2} \mathrm{O}_{2}\right)$, sodium isothiocyanate, dimethyl sulfoxide (DMSO), $\mathrm{FeCl}_{3}$, nitric acid, acetone, methanol and formalin, Triton X100 , beta- glycerol phosphate, $\mathrm{NHCl}$, and paraformaldehyde were purchased from Merck (Darmstadt, Germany). AB-human serum, propidium iodide (PI), hydrocortisone, isobutyl methyl xanthine, indomethacin, Oil Red stain, Alizarin Red stain, dexamethasone, ascorbic acid 2-phosphate, 3-(4,5-dimethylthiazol-2-yl)2,5-diphenyltetrazolium bromide $99 \%$ (MTT), pnitrophenyl phosphate (pNP), Ficoll, and TRIzol were from Sigma-Aldrich (St Louis, MO, USA). IntraStain kit (Code-Nr.K2311) and all of the antibodies were obtained from Dako (Glostrup, Denmark) and Standard SYBR Green PCR kit from Fermentas, St. Leon-Rot, Germany.

The list of the equipment and instruments used is as follows: FACS Calibur (Becton Dickinson, Cockeysville, MD, USA), absorbance micro plate readers (ELx $800^{\mathrm{mm}}$; BioTek, Winooski, VT, USA), Rotor Gene 6000 instrument (Corbett, Sydney, Australia), and scanning electron microscope VEGA-TESCAN-LMU model.

\section{Experimental overview}

Bone marrow collection was approval by Shahid Beheshti University of Medical Sciences, Tehran, Iran (7808) and informed consent was obtained from the patients who participated in the study. The isolation and expansion of hMSCs was performed using the standard protocol [5].

At hMSCs isolation day from bone marrow aspirates, cells were isolated from part of the isolated hMSCs and pluripotency markers and spontaneous differentiation markers were evaluated, Fig. 1.

The remnants of the isolated cells were aliquoted in two parts: control (without GFc7) and test cells (with GFC7); the test cells had GFc7 nanocomplex at a 


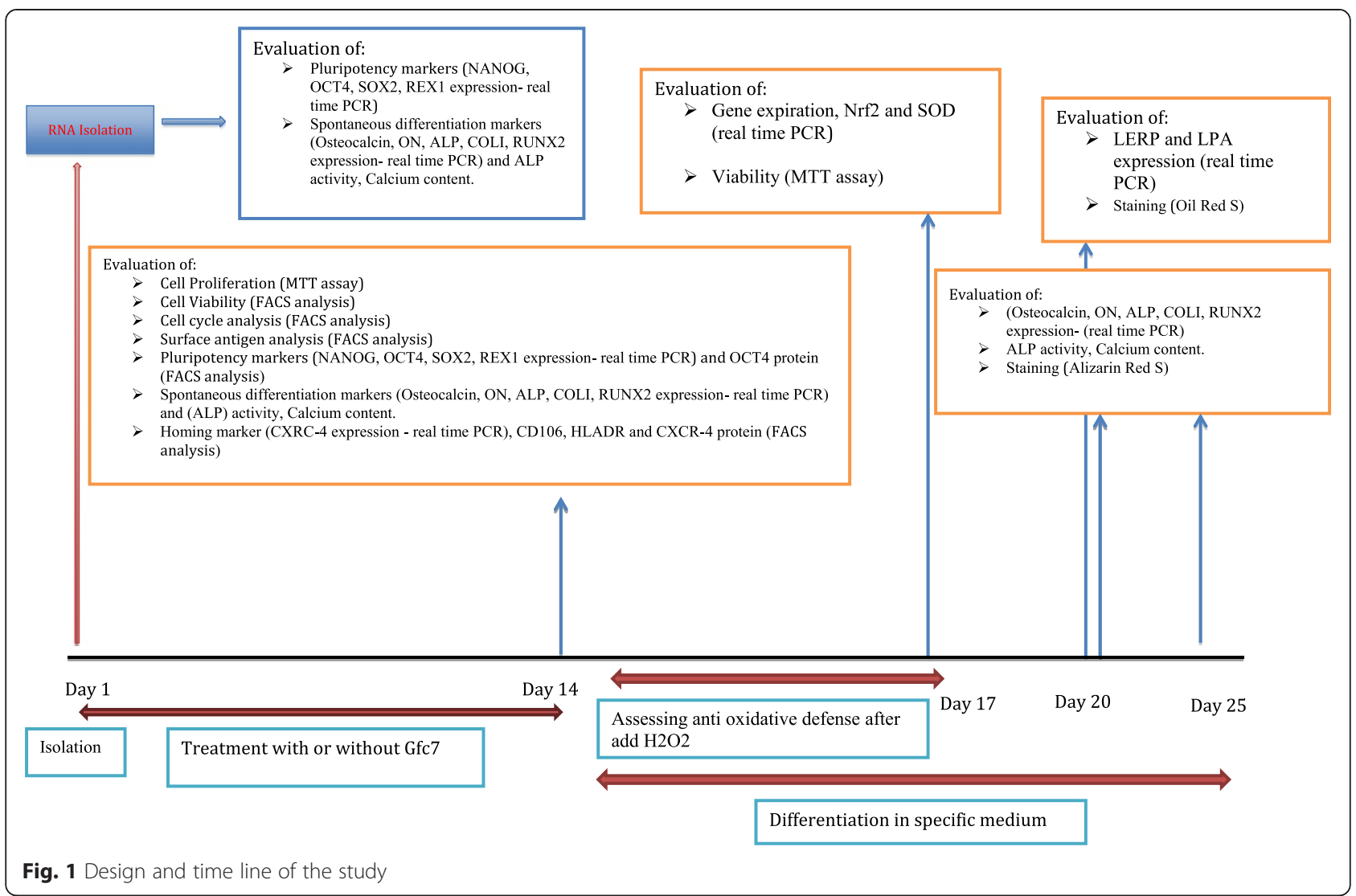

concentration of $0.1 \mathrm{mg} / \mathrm{mL}$ in hMSCs specific medium. (This concentration was determined based on seven days treatment of hMSCs with different concentrations of GFc7 and then cell proliferation assay by the MTT method). Then, the following properties were compared in the control and test cells after 14 days culture (see Fig. 1):

- Cell viability

- Cell cycle analysis, surface antigen analysis

- Pluripotency markers

- Spontaneous differentiation markers

- Homing marker

- Pluripotency markers

- Spontaneous differentiation markers

After 14 days of incubation, control and test groups were analyzed for differentiation (adipogenic and osteogenic) and antioxidative defense was assessed, Fig. 1.

\section{Characterization of GFc7 nano-complex}

Nanochelating technology [15] was used by the Sodour Ahrar Shargh Company to design and synthesize a novel multi-layered nanosphere, which has an iron donor and copper acceptor structure. This multi-layer nanosphere, synthesized by liquid phase reduction, is called GFc7.

\section{Synthesis}

A) Iron-chelate nanosphere preparation:

Special sized iron nanospheres were produced based on liquid phase polymerization by using an organic acid. The method does not need protective agents to prevent the agglomeration of the iron-nanospheres. Controlling the mole ratio of ferrous sulfate and organic acid can produce special sized ironnanospheres. First, $1 \mathrm{ml}$ of $0.5 \mathrm{M}$ organic acid was dissolved in $100 \mathrm{ml}$ of $\mathrm{H} 2 \mathrm{O}$ with stirring and heating to $90{ }^{\circ} \mathrm{C}$ simultaneously. Afterwards, $30 \mathrm{ml}$ of $2.5 \mathrm{mM}$ ferrous sulfate was injected into the solution rapidly and the reaction mixture was maintained at the boiling point for four to seven min before it was allowed to cool to room temperature. When the solution was clear green, the initial iron colloid was condensed by filtering several times to remove unreacted materials to prevent it from agglomerating. The iron-nanospheres can be stable for three days in the dark at $25^{\circ} \mathrm{C}$.

B) Copper-chelator polymerization: 
The prepared iron nanospheres were immersed in $20 \mathrm{~mL}$ of saturated glutaric acid solution. After one h, $8 \mathrm{ml}$ ethanol was added; then the solution was heated to $40{ }^{\circ} \mathrm{C}$ and stirred slowly for about three $\mathrm{h}$ to start growth progression of glutaric acid on the surface of the prepared iron-nanospheres. Afterward, the solution was left to cool for $24 \mathrm{~h}$ to precipitate the final GFc7 multi-layer nanospheres. Then, it was filtered and dried at $100{ }^{\circ} \mathrm{C}$.

\section{Scanning electron microscopy and infrared spectra (IR)}

The surface morphology of this nano-complex was characterized using scanning electron microscopy (SEM) at the Razi Metallurgical Research Center.

GFC7 functional groups were characterized by IR in the $400-4,000 \mathrm{~cm}^{-1}$ range at the University of Shahid Beheshti.

\section{Evaluation of GFc7 toxicity}

Standard tests were carried out to assess the median lethal dose (LD50) according to the guidelines of the Organization for Economic Co-operation and Development (OECD, guideline 420), in the School of Pharmacy at Tehran University of Medical Sciences [20].

\section{hMSC isolation and culture}

Bone marrow aspirates, collected on ACD-heparin, were used to isolate hMSCs by the Ficoll density gradient protocol. The expansion medium included DMEM F12 supplemented with $10 \%$ human serum, penicillin G, streptomycin, Glutamax and nonessential amino acids. The cells were cultured in flasks and were incubated under a humidified atmosphere with $5 \% \mathrm{CO} 2$ at $37{ }^{\circ} \mathrm{C}$.

The cells were then sorted through their surface markers by flow cytometry analysis and their differentiation to osteogenic, adipogenic lineages [5].

\section{Real-time polymerase chain reaction analysis}

Total RNA was extracted using TRIzol according to the manufacturer's instructions. Synthesis of cDNA was carried out with $\mathrm{M}-\mathrm{MuLV}$ reverse transcriptase and oligo (dT) primers. Real-time polymerase chain reaction (qRT-PCR) was performed using a standard SYBR Green PCR kit protocol on a Rotor Gene 6000 instrument [24, 25]. Data were normalized to GAPDH as the endogenous control gene. The relative mRNA expression levels were calculated based on the $\triangle \mathrm{CT}$ method. The list of primers is shown in Table 1.

\section{Differentiation potential}

After hMSCs maintenance in media with and without GFc7 for 14 days, cells were cultured in specific differentiation (adipogenic and osteogenic) media.

Adipogenic differentiation was confirmed by Oil Red staining analysis. For osteogenic differentiation for
Table 1 Primers for qRT-PCR genes

\begin{tabular}{|c|c|c|}
\hline & Genes & Primer sequences \\
\hline \multirow[t]{2}{*}{1} & \multirow[t]{2}{*}{ ALP } & FW, 5'- GCA CCT GCC TTA CTA ACT C -3'; \\
\hline & & RW, 5'- AGA CAC CCA TCC CAT CTC - $3^{\prime} ;$ \\
\hline \multirow[t]{2}{*}{2} & \multirow[t]{2}{*}{ COL1 } & FW, 5'- TGG AGC AAG AGG CGA GAG -3'; \\
\hline & & RW, 5'- CAC CAG CAT CAC CCT TAG C - 3'; \\
\hline \multirow[t]{2}{*}{3} & \multirow[t]{2}{*}{ CXCR4 } & FW, 5-' CGC CAC CAA CAG TCA GAG -3' ; \\
\hline & & RW, 5'- AAC ACA ACC ACC CAC AAG TC - 3'; \\
\hline \multirow[t]{2}{*}{4} & \multirow[t]{2}{*}{ GAPDH } & FW, 5'- GACAAGCTTCCCGTTCTCAG-3'; \\
\hline & & RW, 5'- GAGTCAACGGATTTGGTCGT-3'; \\
\hline \multirow[t]{2}{*}{5} & \multirow[t]{2}{*}{ H-P53 } & FW, 5'- GGA GTA TTT GGA TGA CAG AAA C - 3'; \\
\hline & & RW, 5'- GAT TAC CAC TGG AGT CTT C - 3'; \\
\hline \multirow[t]{2}{*}{6} & \multirow[t]{2}{*}{ LERP } & FW, 5'- CAA TCT GAA TGA AAC CAA ACC TC -3'; \\
\hline & & RW, GGC TGC TCC TAT GAT ACC TC - $3^{\prime} ;$ \\
\hline \multirow[t]{2}{*}{7} & \multirow[t]{2}{*}{ REX1 } & FW, 5'- CGG GAC GAG GAG TGT TAT TAC - 3'; \\
\hline & & RW, 5'- CGT GTT GCT TTG CGA CTT G -3'; \\
\hline \multirow[t]{2}{*}{8} & \multirow[t]{2}{*}{ RUNX2 } & FW, 5'- GCC TTC AAG GTG GTA GCC C - 3'; \\
\hline & & RW, 5'- CGT TAC CCG CCA TGA CAG TA -3' \\
\hline \multirow[t]{2}{*}{9} & \multirow{2}{*}{$\begin{array}{l}\text { Lipoprotein } \\
\text { lipase }\end{array}$} & FW, 5'- CCC TAC AAA GTC TTC CAT TAC - 3'; \\
\hline & & RW, 5'- AGT TCT CCA ATA TCT ACC TCT G -3'; \\
\hline \multirow[t]{2}{*}{10} & \multirow[t]{2}{*}{ NRF2 } & FW, 5'- GCG ACG GAA AGA GTA TGA G -3'; \\
\hline & & RW, 5'- GGG CAA CCT GGG AGT AG -3'; \\
\hline \multirow[t]{2}{*}{11} & \multirow[t]{2}{*}{ NANOG } & FW, 5'- GCT AAG GAC AAC ATT GAT AGA AG -3'; \\
\hline & & RW, 5'- CTT CAT CAC CAA TTC GTA CTT G -3'; \\
\hline \multirow[t]{2}{*}{12} & \multirow[t]{2}{*}{ Osteonectin } & FW: 5': CTCGCTTCGGCAGCACACATATAC-3', \\
\hline & & RW: 5'- ACGCTTCACGAATTTGCGTGTC-3'. \\
\hline \multirow[t]{2}{*}{13} & \multirow[t]{2}{*}{ Osteocalcin } & FW, 5-' GCA AAG GTG CAG CCT TTG TG -3' ; \\
\hline & & RW, 5'- GGC TCC CAG CCA TTG ATA CAG -3'; \\
\hline \multirow[t]{2}{*}{14} & \multirow[t]{2}{*}{ OCT-4 } & FW, 5'- CGC CGT ATG AGT TCT GTG -3'; \\
\hline & & RW, 5'- GGT GAT CCT CTT CTG CTT C - 3'; \\
\hline \multirow[t]{2}{*}{15} & \multirow[t]{2}{*}{ sox2 } & FW; 5'- GGA CTG AGA GAA AGA AGA GGA G -3' \\
\hline & & RW, 5'- GAA AAT CAG GCG AAG AAT AAT-3'; \\
\hline \multirow[t]{2}{*}{16} & SOD1 & FW, 5'- CGA GCA GAA GGA AAG TAA TG -3'; \\
\hline & & RW, 5'- TGG ATA GAG GAT TAA AGT GAG G -3'; \\
\hline
\end{tabular}

indicating calcium mineralization, samples were stained by Alizarin Red. Evaluation of ALP activity and calcium content measurements were performed for osteogenic differentiation. All tests were done according to standard protocols $[5,19]$.

\section{Flow cytometry analysis}

In all of the following tests, cell surface, intracellular proteins and cell viability assessment were performed by flow cytometry analysis (FACS). Data were analyzed using Win MDI 2.8 software, and the results were illustrated using histograms and dot plots [25]. 
A) Cell surface:

A total of $1 \times 10^{5}$ cells was allocated into $2 \mathrm{ml}$ microtubes with $100 \mu \mathrm{l}$ PBS. Then, they were stained at $4{ }^{\circ} \mathrm{C}$ for 30 min with monoclonal antibodies against the following: fluorescein isothiocyanate conjugated human CD34, CD44, CD90, and CD105 and PE-conjugated CD73, CD166, and HLADR. In each test, the suitable isotype matching the antibody was used as control to cover nonspecific binding. Cells were fixed with $1 \%$ paraformaldehyde in PBS.

B) Intracellular proteins:

For monoclonal antibodies against human OCT4, sample preparation and staining procedures were performed using the IntraStain kit (Code-Nr.K2311) according to the manufacturer's protocol [21].

C) Cell viability assessment

To adjust flow cytometer settings for PI, we added staining solution with gentle mixing and incubation for one min in the dark. PI fluorescence was determined with a FACS [25].

\section{MTT assay}

The fallowing tests, were performed by MTT assay according to the standard protocols [17].A) The MTT Cell Proliferation Assay measures the cell proliferation rate.B) Measuring cell-protection capacity against $\mathrm{H} 2 \mathrm{O} 2$-induced oxidative injuryIn the experimental studies, $\mathrm{H} 2 \mathrm{O} 2$ is used for simulating OS-induced cell death [23]. The hMSCs were plated at a density of 1x104 cells/well in 96-well plates in $100 \mu \mathrm{l}$ specific medium. The cells were treated with GFc7 $(0.01 \mathrm{mg} / \mathrm{mL})$ for 14 days and were then incubated with $5 \mu \mathrm{M}$ of $\mathrm{H} 2 \mathrm{O} 2$ for 72 hours. For the control group, hMSCs cells were cultured without treatment with GFc7 or $\mathrm{H} 2 \mathrm{O} 2$ (as negative control) and were treated simply with $\mathrm{H} 2 \mathrm{O} 2$ for 72 hours (as positive control), after that, MTT assay and qRT-PCR analysis were performed.

\section{Measuring cell-protection capacity against $\mathrm{H} 2 \mathrm{O} 2$-induced oxidative injury}

In the experimental studies, $\mathrm{H} 2 \mathrm{O} 2$ is used for simulating OS-induced cell death [23]. The hMSCs were plated at a density of $1 \times 10^{4}$ cells/well in 96-well plates in $100 \mu \mathrm{l}$ specific medium. The cells were treated with GFc7 $(0.01 \mathrm{mg} / \mathrm{mL})$ for 14 days and were then incubated with $5 \mu \mathrm{M}$ of $\mathrm{H} 2 \mathrm{O} 2$ for 72 hours. For the control group, hMSCs cells were cultured without treatment with GFc7 or $\mathrm{H}_{2} \mathrm{O}_{2}$ (as negative control) and were treated simply with $\mathrm{H}_{2} \mathrm{O}_{2}$ for 72 hours (as positive control), after the MTT assay and qRT-PCR analysis were performed.

\section{Statistical analysis}

Student's t-test was used to determine whether there was a significant difference between the groups. In order to compare multiple groups, the analysis of variance (ANOVA) test was applied; the difference was considered significant if the $\mathrm{P}$ value was lower than 0.05. All data are shown as mean \pm standard deviation (SD).

\section{Results}

\section{GFc7 characterization}

SEM images showed that the size of the GFc7 nanocomplex in the first synthesis step (iron-chelate nanosphere) was $18 \mathrm{~nm}$ (Fig. 2a) and after the progression of the copper-chelator polymerized on the surface of the iron-chelate nanosphere, it was approximately $85 \mathrm{~nm}$ (Fig. 2b).

The IR spectrum analyses clearly demonstrated that GFc7 was an organic structure containing carbonyl, alcohol, and amide groups. At $3,400 \mathrm{~cm}^{-1}$, carboxylic acid $\mathrm{C}-\mathrm{H}$ bonds could be found. At 3,000 $\mathrm{cm}^{-1}$, O-H stretch is shown. The carboxylic acid structure appears as a wide, broad peak spectrum between 2,000 to $3,000 \mathrm{~cm}^{-1}$ (Fig. 2c).

Toxicity reports indicated that the intraperitoneal LD50 of this nano complex was $68.190 \mathrm{mg} / \mathrm{kg}$ for mouse and was thus considered to have low toxicity. However, its oral LD50 for mouse was $752.63 \mathrm{mg} / \mathrm{kg}$, classifying it as non-toxic.

\section{hMSC characterization}

After isolation and adherence to cell culture flasks, hMSCs were morphologically spindle shaped. The identity of the cells was determined by confirming that the surface markers were positive for $\mathrm{CD} 90,73$, and 105 and negative for CD 45, 34, and 117 (Fig. 3a) and their differentiation to adipogenic lineages (Fig. 3b) and osteogenic lineages (Fig. 3c).

\section{GFc7 increased proliferation with a normal cell cycle}

The cells were treated with $0.1 \mathrm{mg} / \mathrm{ml}, 0.02 \mathrm{mg} / \mathrm{ml}$, and $0.01 \mathrm{mg} / \mathrm{ml}$ doses of GFc7 for seven days and proliferation improved, respectively, by $3.7 \pm 0.035,3.1 \pm 0.025$, and $3.2 \pm 0.032$-fold and by $2.9 \pm 0.026$-fold in the control group (Fig. 4a).

The results from the cell cycle analyses in the control and test groups were $\mathrm{S}=13.5, \mathrm{G} 2=1.5, \mathrm{G} 1=85$ and $\mathrm{S}=6$, $\mathrm{G} 2=9, \mathrm{G} 1=85$, respectively. In the control cells, however, decreases in the G2 phase of the cell cycle analysis were noticed (Fig. 4b).

\section{GFc7 had no negative effects on cell viability}

The percentage of cell viability between the test and control groups was equal to $98.5 \pm 1 \%$ (Fig. 4c).

\section{GFc7 efficiently increased hMSCs pluripotency}

On day 7, the expression of NANOG, SOX2, OCT4, and REX1 in the test hMSCs increased by $197 \pm 10,2,300 \pm$ 


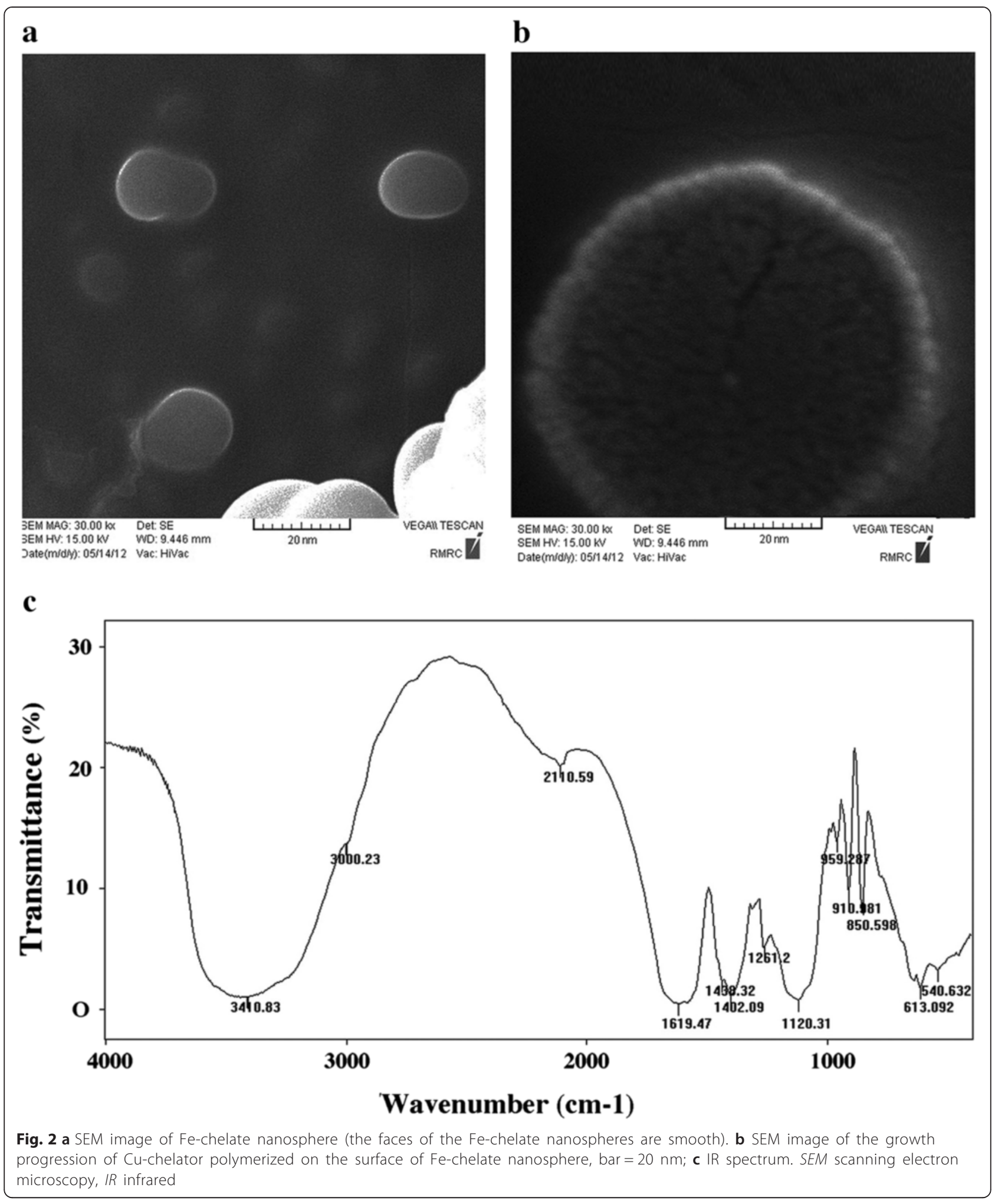

97, $61 \pm 8$ and $30 \pm 2$-fold, respectively, compared with that of the control cells (Fig. 5a).

On day 14, the expression of NANOG, SOX2, OCT4, and REX1 in the test cells increased respectively by $63 \pm$
4, $31 \pm 7,8.3 \pm 1$, and $1.8 \pm 0.05$-fold compared with the control group (Fig. 5b).

Comparing these two groups with the cells from the isolation day verified maintenance of pluripotency in the 

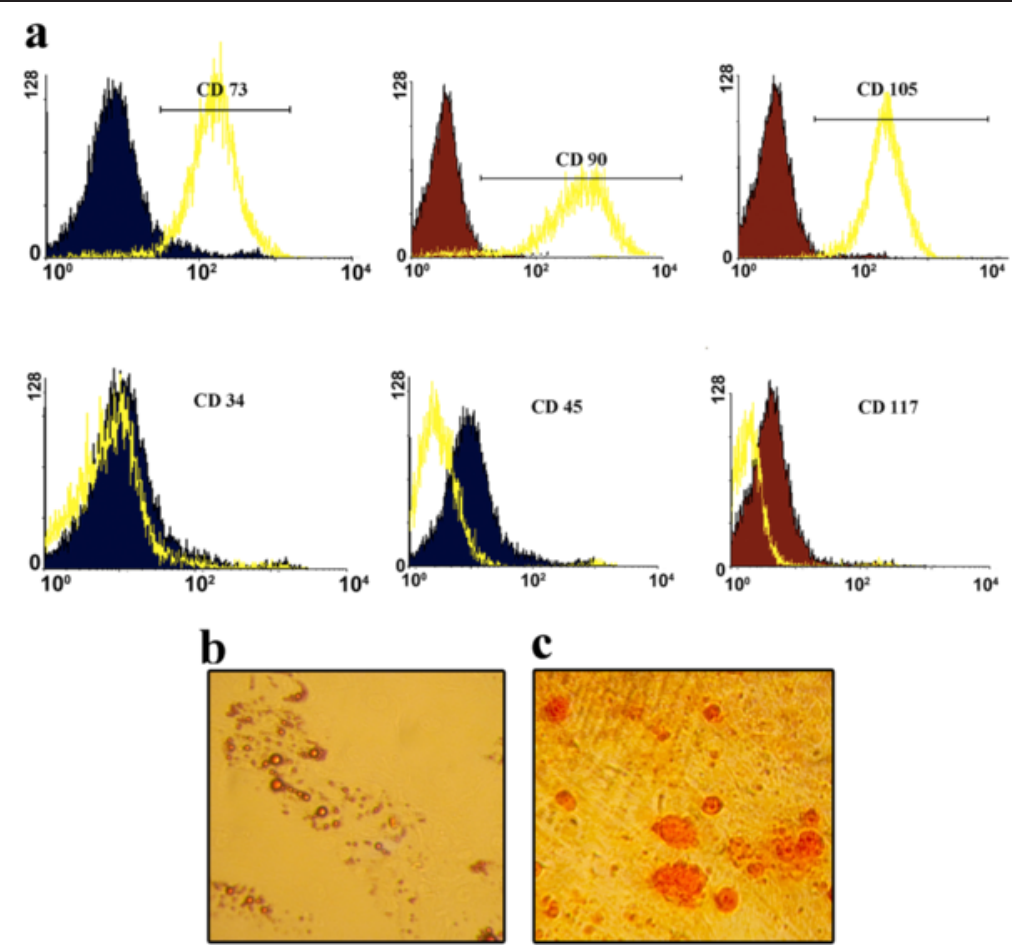

Fig. 3 a Cells expressed hMSc markers. The cells were negative for CD34, CD45, and CD 117 but were positive for CD 73, CD90, and CD105. b The ability for lipogenic differentiation was assessed by staining with Oil Red. c The ability for osteogenesis differentiation was assessed by staining with Alizarin (400 X magnification). hMSc mesenchymal stem cell.

treated cells. In the test cells, the expression of NANOG, SOX2, OCT4, and REX1 increased by $218 \pm 30,8 \pm$ $0.4,14 \pm 1$ and $6 \pm 1$-fold, while in the control cells, the expression increased by $85.4 \pm 10,4.6 \pm 0.3,0.4 \pm 0.03$ and $0.3 \pm 0.01$-fold, respectively. (Fig. 5c).

The histogram graphs demonstrated that OCT4 expression increased by $30 \%$ in the test cells relative to the control (Fig. 5d).

\section{GFc7 inhibited spontaneous differentiation}

The main issue in cell therapy is the lack of spontaneous differentiation of the cells during in vitro culture. In this study, the cells were examined for the expression of osteogenic specific genes. Relative to the cells obtained on isolation day, the expression of osteocalcin $(\mathrm{OCN})$, osteonectin (ON), alkaline phosphatase (ALP), COLI, and RUNX2 in the test group changed by $1 \pm 0.9,2.2 \pm$ $0.5,0.17 \pm 0.8,0.34 \pm 0.04$, and $1.27 \pm 1.2$-fold, respectively. In the control group, these values increased by $1.5 \pm 1.4$, $5.02 \pm 1,0.2 \pm 0.1,2.94 \pm 1.5$, and $5.1 \pm 1$-fold, respective to the cells from the isolation day (Fig. 6a). Although calcium content was equal (Fig. 6b), GFc7 induced greater levels of ALP in the test cells compared to the control group (Fig. 6c).

\section{GFc7 promoted hMSCs-specific markers}

After 14 days of cell proliferation, the expression levels of surface antigens and the mean fluorescence intensity (MFI) of MoAb-reacted proteins [26] were analyzed in different groups (control and test). Data are shown in the Tables 2 and 3.

\section{Protected hMSCs against $\mathrm{H} 2 \mathrm{O} 2$ induced cell toxicity}

In the positive control group, cell viability was $58.7 \pm$ $2 \%$. In the test group, cell viability increased significantly to $83 \pm 3 \%$. (Fig. 7a).

Real-time PCR was used to assess nuclear factor (erythroid-derived 2)-like 2 (Nrf2) and superoxide dismutases (SOD) gene expression at the optimum dose, demonstrating a $3.3 \pm 0.5$-fold increase (Nrf2) and a 6.6 \pm 0.8 -fold increase (SOD) in the test group relative to the controls (Fig. 7b). Nrf2 and SOD gene expression was $1.04 \pm 0.02$ and $1.3 \pm 0.03$ in the test group and $0.314 \pm 0.02$ and $0.198 \pm 0.01$ in the control group relative to the isolation test (Fig. 7c).

\section{GFc7 efficiently increased markers associated with cell homing}

After 14 days of cell proliferation, under the optimal dose of GFc7, C-X-C chemokine receptor type 4 (CXCR- 

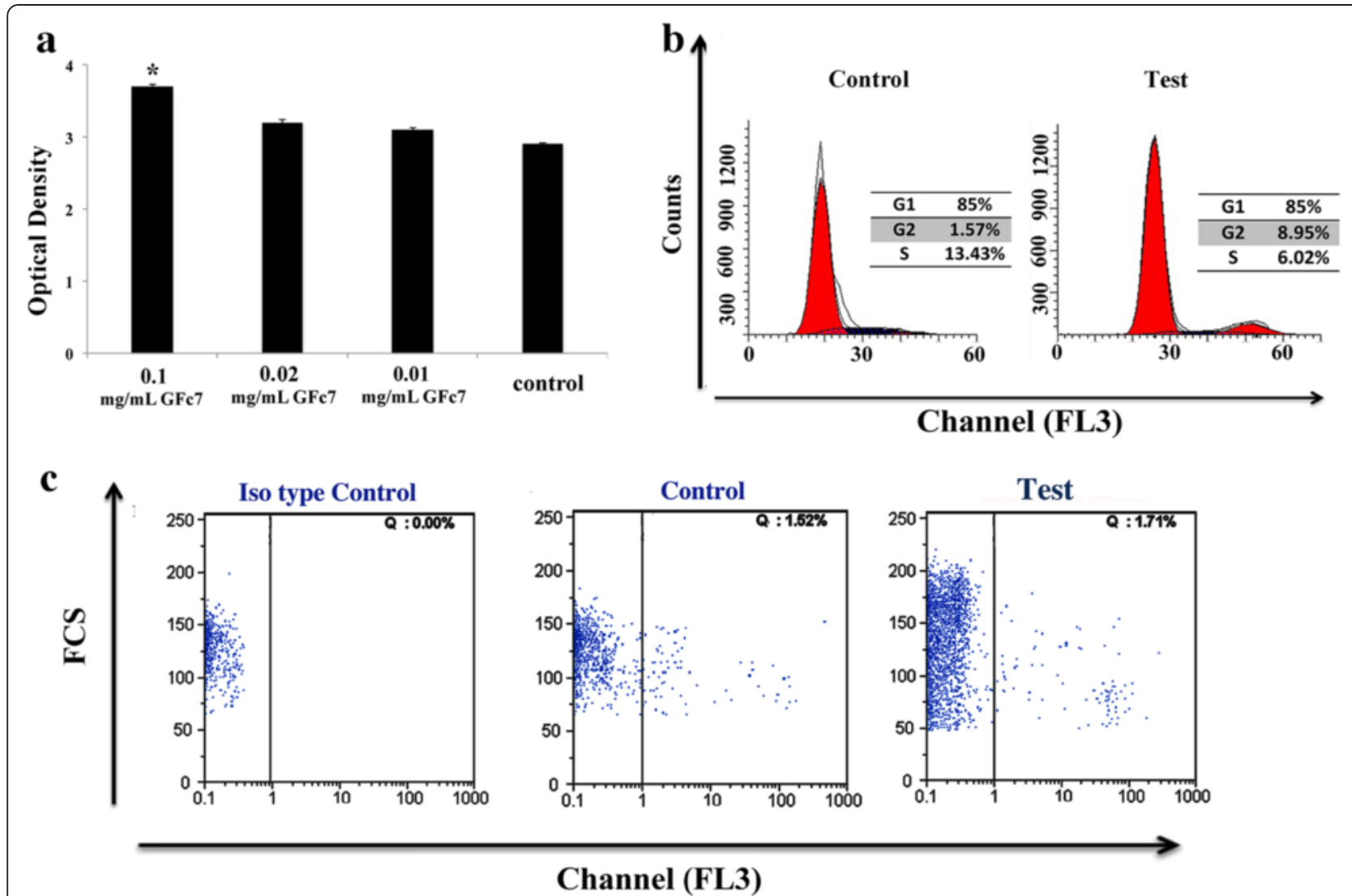

Fig. 4 a The MTT Cell Proliferation Assay. b FACS analysis of cell cycle parameters. c Cell viability assays by flow cytometry. (data shown with dot plot diagram). (Isotype control is an antibody of the same isotype as a primary antibody with no relevant specificity to the target antigen and it used as negative controls to help differentiate non-specific background signal from specific antibody signal). Data are expressed as mean \pm SD. Asterisks show significant differences with $p<0.05$. hMSCs human mesenchymal stem cells, Pl propidium iodide

4) expression increased by $8 \pm 1$-fold (Fig. 8a), and its protein level increased by $5 \pm 0.5 \%$ in comparison with the control group (Fig. 8b). hMSCs are known to be negative for HLADR, but as observed in the flow cytometry graph, the quantity of HLADR in the control cells was $2 \%$, compared with $0 \%$ in the test groups. This result demonstrated that GFc7 preserved the suppression of HLADR expression during treatment (Table 2). Unlike the expression of CD106 in the control group (0\%), the expression of CD106 in the treated cells was approximately $20 \pm 1 \%$ (Table 2 ).

GFc7 promoted quality and rate of hMSCs differentiation After pretreating hMSCs with the GFc7, the cells were put through adipogenic differentiation in specific medium. A higher rate of differentiation in the pretreated cells, compared against the control, was confirmed by various tests.

The percentage of adipogenic differentiation capability of hMSCs by Oil Red staining after five days of induction between the test and control groups was $75 \pm 6 \%$ and $25 \pm 4 \%$, respectively (Fig. 9a) and expression of the adipogenic genes LERP and LPA on day 5 improved, respectively, by $164 \pm 20$ and $90 \pm 20.1$-fold compared with the control (Fig. 9b).

In the osteogenic differentiation, nodules of mineral aggregations could be observed which were stained by Alizarin Red S. Staining was carried out on day 10 of the differentiation process and indicated a higher rate of differentiation in the treated cells compared to the control. The percentage of differentiation among the test and control cells was $50 \pm 5 \%$ and $20 \pm 4 \%$, respectively (Fig. 10a).

Compared with the control in the osteogenic differentiation assay the expression of OCN, ON, ALP, COLI, and RUNX2 in test cells grew, respectively, by $13.5 \pm 2$, $1.5 \pm 0.2,5.7 \pm 1,2 \pm 0$, and $2.5 \pm 0.5$-fold at the fifth day after the initiation of the differentiation process and by $0.9 \pm 0.01,0.3 \pm 0.01,1 \pm 0.02,0.1 \pm 0.02$ and $0.6 \pm 0.1-$ fold ten days after initiating the differentiation process (Fig. 10b). Calcium content assays indicated that the $\mathrm{Ca}^{2+}$ level in the control and test cells was $0.62 \pm 0.01$ and $0.96 \pm$ 0.132 , respectively, after five days of osteogenic treatment and $2.7 \pm 0.48$ and $3.5 \pm 0.51$ after ten days of 


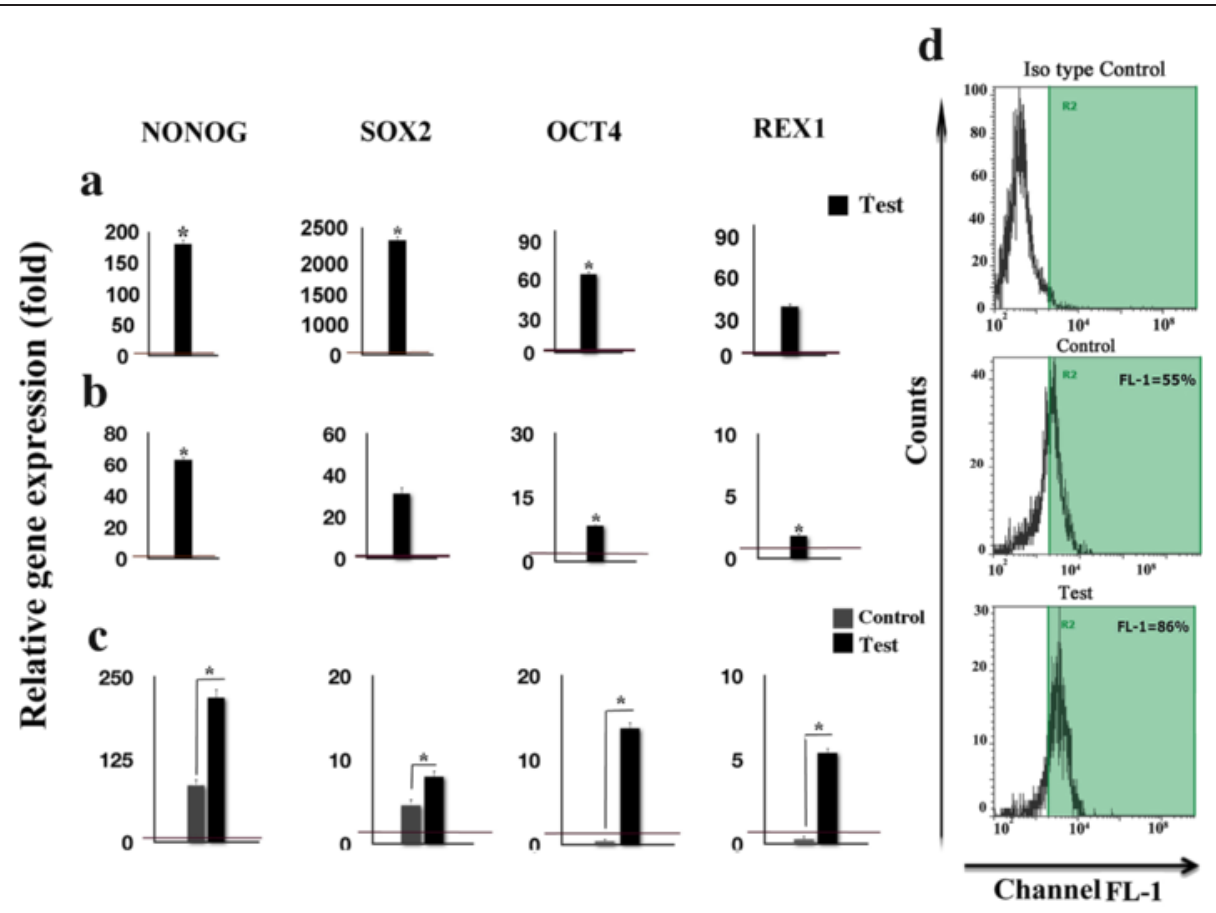

Fig. 5 a Relative expression level of pluripotency genes (NONOG, SOX2, OCT-4, and REX1) on day 7 of the test compared with control. b Relative expression level of pluripotency genes (NONOG, SOX2, OCT-4, and REX1) on day 14 of the test compared with control. c Relative expression levels of pluripotency genes (NONOG, SOX2, OCT-4, and REX1) in the two groups (test and control) were compared with the cells obtained on the isolation day. $\mathbf{d}$ Flow cytometric analysis of Oct-4 expression. The red horizontal line shows the one-fold enrichment cut off criteria. Data are expressed as mean $\pm \mathrm{SD}$; Asterisks show significant differences with $p<0.05$

differentiation (Fig. 10c). ALP activity level was measured and found to be $0.142 \pm 0.005$ (control) and $0.163 \pm 0.01$ (test) after five days and $0.32 \pm 0.01$ and $0.34 \pm 0.01$ after ten days (Fig. 10d).

\section{Discussion}

Human mesenchymal stem cells are undifferentiated cells responsible for the growth, homeostasis and repair of many tissues [27]. Although stem cells hold great potential for the treatment of many injuries and degenerative diseases, several obstacles must be overcome before their therapeutic application can be realized [28]. The application of nanotechnology to stem cell biology would be able to address these challenges [29].

Nanostructures are of particular interest because they have the advantageous features of a high surface-tovolume ratio and small size $(1-100 \mathrm{~nm})$ [30] and they elicit a higher degree of biological plasticity compared with conventional micro- or macro-structures [31]. In the field of biomaterial development and in vivo implant technology, the nanoscale structure and morphologic factor of the surface have played a critical role in accelerating the rate of cell proliferation and enhancing tissue acceptance with a reduced immune response [31].

Particle size is the most important and most studied factor affecting nanoparticle toxicity. Nanoparticles that are too small (e.g., $<10 \mathrm{~nm}$ ), cause damage. In contrast, particles $>100 \mathrm{~nm}$ do not possess the desired pharmacological properties for effective delivery [32].

Recently nanochelating technology [15] synthetized and introduced novel nano complexes based on a selfassembly method $[16,17,33]$.

In the present study, Gfc7 as a novel iron containing copper chelator efficiently and in a balanced manner increased hMSCs quantity and quality characters. SEM images showed that first we had a Fe-chelate nanosphere, then growth progression of $\mathrm{Cu}$-chelator polymerized on the surface of the Fe-chelate nanosphere.

Also the SEM image showed that the size of the GFc7 nano-complex was $85 \mathrm{~nm}$ and the IR spectrum analyses demonstrated that this nanocomplex was an organic structure.

Assessing the influence of GFc7 on the pluripotency potential of hMSCs indicated that GFC7 could significantly increase cell proliferation and simultaneously improve the expression of the pluripotency markers OCT4, SOX2, NANOG, and REX1 at day 7 and 14 after isolation compared with control cells.

The physiological role of iron in cell proliferation is a known concept, because several important enzymes in the cell cycle progression and DNA synthesis are iron dependent [34]. Huang et al. evaluated the effects of 

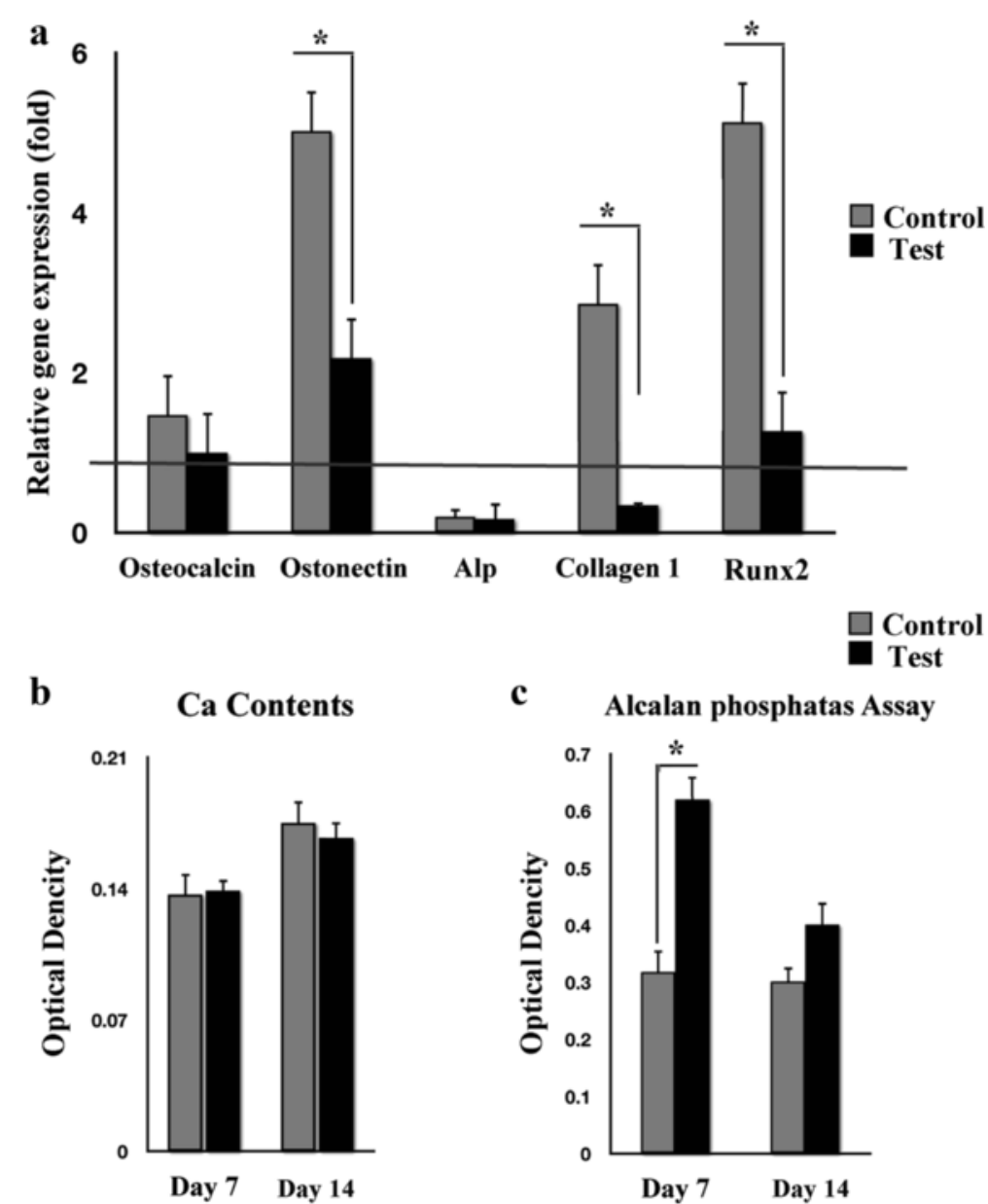

Fig. 6 a Effect of GFC7 nanocomplex on spontaneous differentiation, relative expression of osteogenic differentiation genes (OCN, ON, ALP, COLI, and RUNX2) in control and test groups were compared to the cells obtained on the isolation day. $\mathbf{b}$ Effect of GFc7 on spontaneous

differentiation on ALP activity of hMSCs in the control and test groups compared to the cells obtained on the isolation day. $\mathbf{c}$ Effect of GFC7 on spontaneous differentiation on calcium content of hMSCs in the control and test groups compared to the cells obtained on the isolation day. The red horizontal line shows the one-fold enrichment cut off criteria. Data are expressed as mean \pm SD. Asterisks show significant differences with $p<0.05$. OCN osteocalcin, ON osteonectin, ALP alkaline phosphatase

Table 2 Percent of CD markers between groups

\begin{tabular}{lll}
\hline CD marker & Control & Test \\
\hline CD73 & $70 \%$ & $91 \%$ \\
CD90 & $93 \%$ & $96 \%$ \\
CD105 & $92 \%$ & $99.5 \%$ \\
CD 106 & Negative & $19 \%$ \\
CD34 & Negative & Negative \\
CD44 & Negative & Negative \\
CD166 & Negative & Negative \\
HLADR & Negative & $2 \%$ \\
\hline
\end{tabular}

Table 3 Percent of mean fluorescence intensity

\begin{tabular}{lll}
\hline GMean & Control & Test \\
\hline CD73 & $16 \%$ & $27 \%$ \\
CD90 & $37 \%$ & $22 \%$ \\
CD105 & $26 \%$ & $23 \%$ \\
CD 106 & Negative & $11 \%$ \\
CD34 & Negative & Negative \\
CD44 & Negative & Negative \\
CD166 & Negative & Negative \\
HLADR & Negative & Negative \\
\hline
\end{tabular}



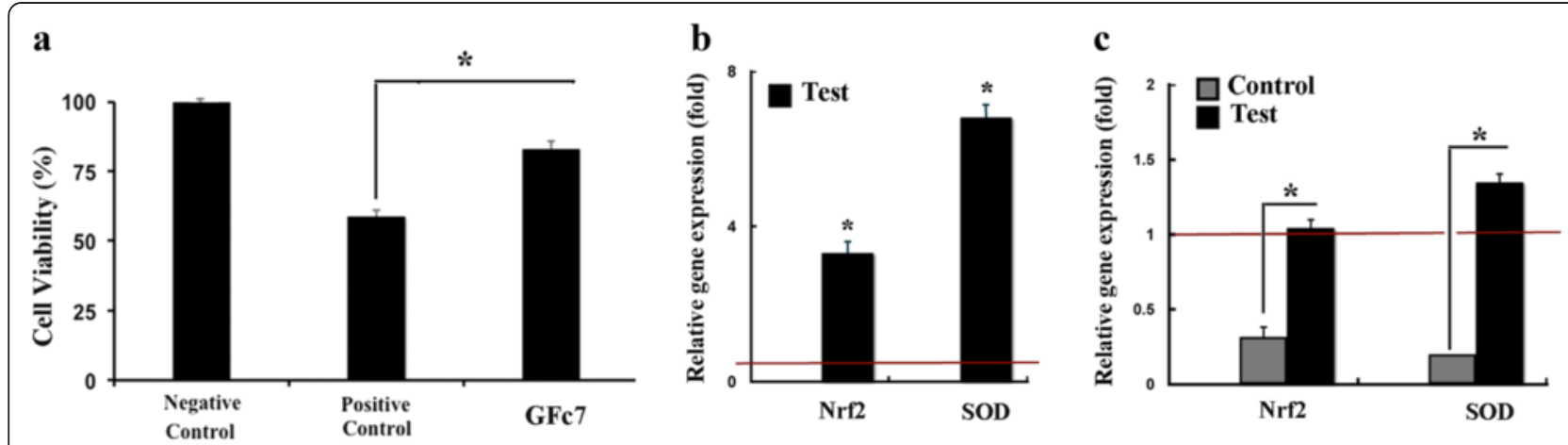

Fig. 7 a hMSCs protection from H2O2-induced oxidative toxicity by GFc7nono complex. b Relative expression of antioxidant gene (Nrf2, SOD) in test group compared to the control after exposure to H2O2. c Relative expression of antioxidant gene (Nrf2, SOD) in test and control groups after exposure to $\mathrm{H} 2 \mathrm{O} 2$ compared to the cells obtained on the isolation day. The red horizontal line shows the one-fold enrichment cutoff criteria. Data are expressed as mean \pm SD. Asterisks show significant differences with $p<0.05$. Nrf2 nuclear factor (erythroid-derived 2)-like 2, SOD

superoxide dismutases

superparamagnetic iron oxide nanoparticles (SPIONs) on hMSCs proliferation and reported that Ferucarbotran, an ionic SPIO, increases hMSCs cell numbers and growth [35].

On the other hand, several studies have shown the role of copper in stem cell differentiation [20]. Peled et al. studied the effects of copper-chloride, copper chelator tetraethylenepentamine (TEPA) and TEPA/copper mixtures on short- and long-term cord blood-derived CD34 (+) cell cultures. The results showed that addition of TEPA, TEPA/copper mixtures up to equimolar concentrations, and the TEPA-Cu complex to CD34(+) cultures resulted in inhibition of differentiation and enhancement of long-term self-renewal of CD34(+) cells which was correlated with reduction in the cellular chelatable $\mathrm{Cu}$ content [36]. Also in the study by Rodríguez et al., copper supplementation diminished the proliferation rate of MSCs, increasing their ability to differentiate into the osteogenic and the adipogenic lineages [37].
It is notable that the expression of these pluripotency markers in GFC7 treated cells was higher compared to the isolation day. In the study by Choudhery et al., they reported that advancing age negatively impacts stem cell function and such age related alterations may be detrimental for successful stem cell therapies. They showed that aged hMSCs displayed senescent features, reduced viability and proliferation and also differentiation potential when compared with cells isolated from young donors [38]. So the increase of pluripotency markers in GFC7 treated cells, compared to the isolation day, suggests the potential of this nano complex as an option for functional improvement of older patients' MSCs.

One of the major concerns regarding the in vitro culture of hMSCs includes their spontaneous differentiation into lineages such as osteogenic cells [39]. Notably, treatment with GFC7 led to a stable level of RUNX-2, an early marker that triggers the osteogenic differentiation cascade [40], and other osteogenic genes in comparison
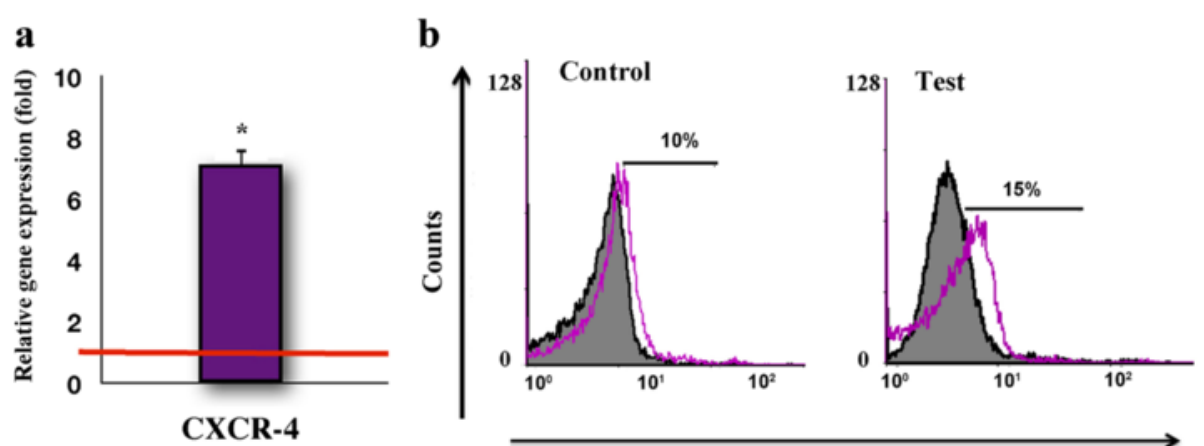

Channel (FL3)

Fig. 8 a Relative expression of CXCR-4 for test compared with control. b Flow cytometric analysis of CXCR-4 expression protein. The red horizontal line shows the one-fold enrichment cutoff criteria. Data are expressed as mean \pm SD. Asterisks show significant differences with $p<0.05$. The dark filled histogram represents the isotype control; the color line histogram represents expression of CXCR4 on hMSCs. CXCR-4 C-X-C chemokine receptor type 4 


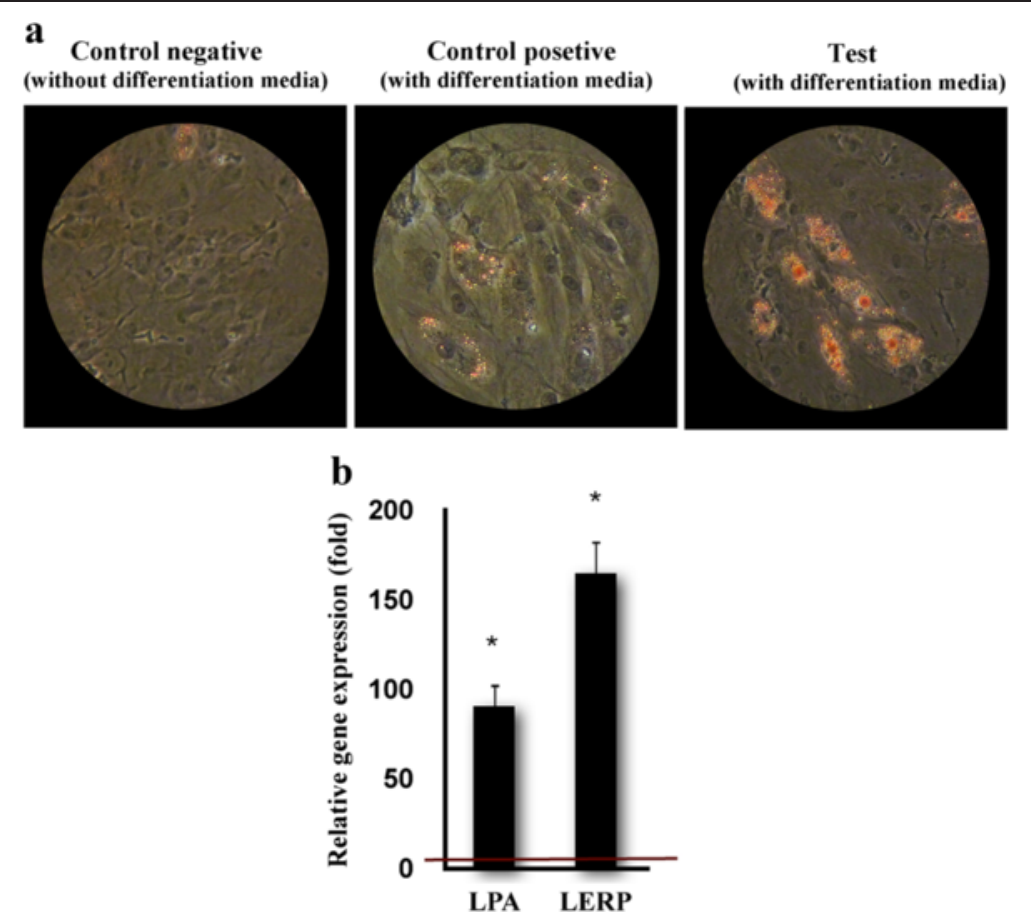

Fig. 9 a The ability for adipogenesis differentiation was assessed by staining with Oil Red $O$ for lipid accumulation (400 X magnification). $\mathbf{b}$ Relative expression of lipogenic-specific genes (LERP, LPA) in test compared with control. The red horizontal line shows the one-fold enrichment cutoff criteria. Data are expressed as mean \pm SD. Asterisks show significant differences with $p<0.05$. LPA lysophosphatidic acid

with the cells obtained on isolation day. However, the expression of RUNX2, ON, and COLI exhibited dramatic increases in the control cells, which signified the beginning of unsuitable differentiation events at genomic levels. Conversely, the GFC7 nano-complex induced greater levels of ALP activity. Considering that ALP is a stemness marker for hMSCs derived from bone marrow, embryonic stem cells, and other sources, GFc7 treatment could be a way to maintain stemness capacity in the test cells [41].

Nrf2 is a transcription factor known as the master regulator of the antioxidative stress response, which protects the cells by upgrading antioxidative defenses [42]. Several studies have demonstrated that Nrf2 is upregulated by hydrogen peroxide, hypoxia, and serum deprivation stresses, and this is in favor of the cell viability $[43,44]$. Nrf2 acts in part by enhancing SODs, key enzymes that reduce reactive superoxide forms [45]. GFc7 could efficiently protect hMSCs viability against $\mathrm{H} 2 \mathrm{O} 2$ induced oxidative stress and induce expression of Nrf2 and SOD compared to control cells. These findings suggest that the nano complex sufficiently promoted the antioxidative defense by improving the expression of these transcription factors against oxidative stress.

Adhesion molecules such as CD106 are among the most fundamental factors in improving the migration rate of transplanted cells from the injection site into the damaged tissues [46] Furthermore, stem cells with intrinsic expression of CXCR-4 on their surfaces have been shown to be suitable candidates in cell therapy and regenerative medicine [47]. Considering the vital roles of CD106 (adhesion molecules) [48] and CXCR-4 in successful cell transplantation, the improved expression of homing markers along with the lack of HLADR expression [49] under GFC7 treatment could promise an improvement in the transplantation of GFC7-treated cells to the damaged areas [46].

The improvement of differentiation potential toward osteogenic or adipogenic features in special differentiation media was confirmed by various tests. It is notable that fat vacuoles (in adipogenic cells) were clearly observed in the cytoplasm of pretreated hMSCs merely five days after adipogenic differentiation, while no sign of differentiation was noticed among the controls in the same time period. Importantly, observation of fat vacuoles mostly happened after seven days of transferring in specific differentiation medium [50]. The expression of LPA and LERP was also assessed, demonstrating significant enhancements in the treated cells, compared to the control.

The enhancement of osteogenic-specific genes was also noticed in the treated cells five days after exposure 

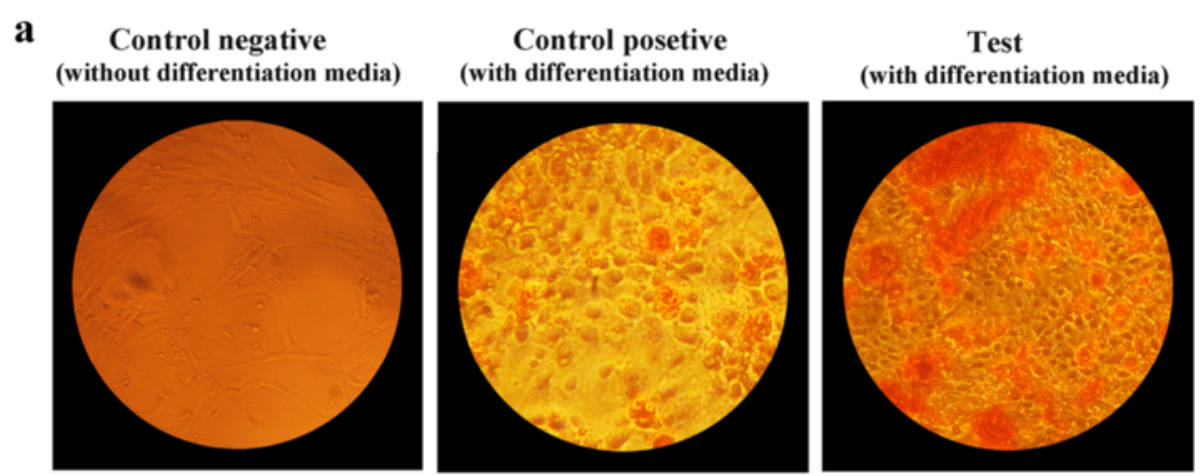

b
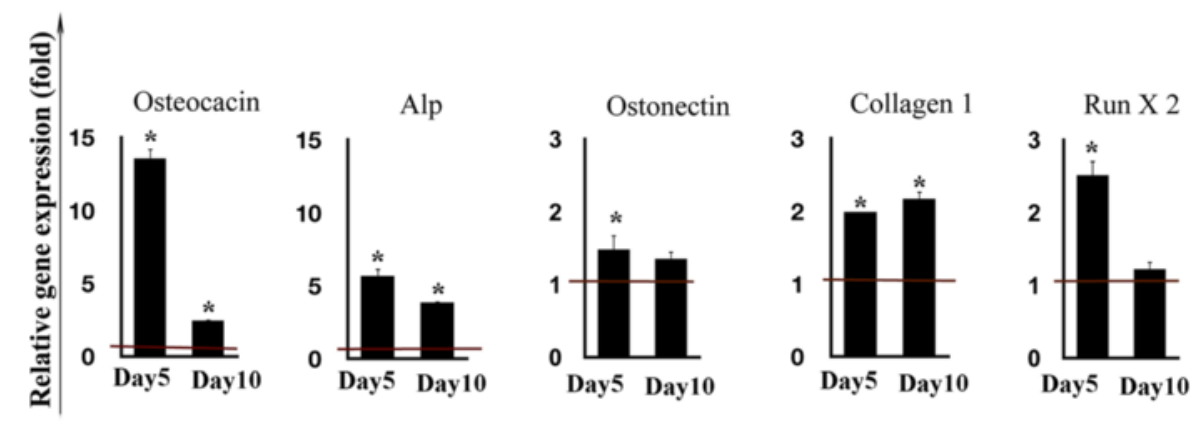

c

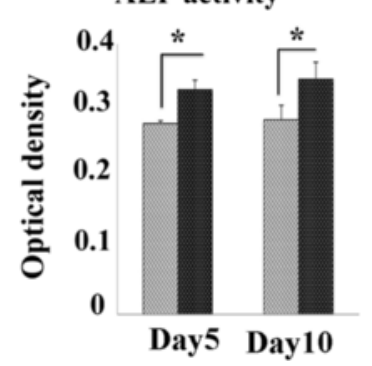

d

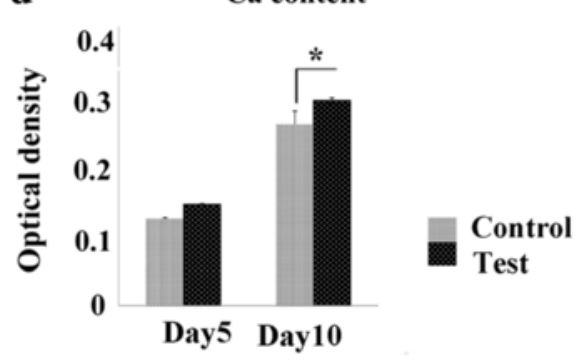

Fig. 10 a The ability for osteogenesis differentiation was assessed by staining with Alizarin Red for calcium deposition (400 X magnification). b Relative expression of osteogenic-specific genes (OCN, ON, ALP, COLI, and RUNX2) for test group on days 7 and 14 compared with control. c ALP activity of hMSCs in the control and test groups during osteogenic differentiation (day 5 and 10). $\mathbf{d}$ Calcium content of hMSCs in the control and test groups during osteogenic differentiation (day 5 and 10). The red horizontal line shows the one-fold enrichment cut off criteria. Data are expressed as mean \pm SD. Asterisks show significant differences with $p<0.05$

to osteogenic differentiation medium. It is noteworthy that the expression of RUNX2 was followed by the promotion of COLI at early stages of differentiation and ALP and OCN at later stages [51]. This enhancement seemed to be functional, resulting in significantly higher ALP activity and calcium content in the test cells compared with the control. CD106 ${ }^{+}$hMSCs have proven to be more capable of differentiating into osteogenic lineages $[51,52]$. The increase in the expression of this protein in the treated cells was further evidence of osteogenic differentiation promotion among these cells.

Altogether, it could be perceived that along with the increased quality of the treated cells, the duration of differentiation was decreased. This was a perfectly purposeful improvement, as the pluripotency characteristics of the cells were efficiently preserved in the medium containing GFc7, and the treated cells differentiated faster and were more competent after exposure to differentiation medium [50].

\section{Conclusions}

The results of our study, including:: nano scale size $10 \mathrm{~nm}<$ e.g., < $100 \mathrm{~nm}$ of GFc7; self-assembly synthesis method; novel nanocomplex (an iron containing copper chelator nano complex); low toxicity in vivo; concomitant enhancement of four pluripotency genes; inhibition 
of spontaneous differentiation; improved cell proliferation along with maintaining and increasing the pluripotency characteristics of hMSCs; an appropriate increase in Nrf2 during exposure to OS; protection of hMSCs against OS-induced damages; and promotion of the quality of hMSCs differentiation by accelerating the differentiation process and increasing the expression of osteogenic- or adipogenic-associated genes.

According to our results, GFc7 with a novel structure has simultaneously affected the apex of the cellular regulatory system and the lower sections.

In conclusion, this study showed that the GFc7 nanocomplex has the potential to be evaluated in complementary studies as an efficient supplement for hMSCs expansion.

\section{Abbreviations}

ALP: Alkaline phosphatase; CXCR-4: C-X-C chemokine receptor type 4; DMSO: Sodium isothiocyanate, dimethyl sulfoxide; GFc7: Iron containing copper chelator nano complex; $\mathrm{H}_{2} \mathrm{O}_{2}$ : Hydrogen peroxide; hMSCs: Human mesenchymal stem cells; IR: Infrared spectra; LPA: Lysophosphatidic acid; MFI: Mean fluorescence intensity; MTT: 3-(4,5-dimethylthiazol-2-yl)-2,5diphenyltetrazolium bromide $99 \%$; Nrf2: Nuclear factor (erythroid-derived 2)like 2; OCN: Osteocalcin; ON: Osteonectin; PBS: Phosphate-buffered solution; PI: Propidium iodide; pNP: p-nitrophenyl phosphate; qRT-PCR: Real-time polymerase chain reaction; SEM: Scanning electron microscopy; SOD: Superoxide dismutases; SPIONs: Superparamagnetic iron oxide nanoparticles; TEPA: Copper chelator tetraethylenepentamine; a-MEM: Minimum essential medium.

\section{Competing interests}

MH Nazaran is owner of Nanochelating Technology and GfC7 nanocomplex was designed and synthesized by this technology. It was registered at US20120100372A1 in the United States Patent Office [15]. The other authors declare that they have no competing interests.

\section{Authors' contributions}

$\mathrm{MH}$ performed experiments, data acquisition and final approval of the version to be published. AH performed experiments and data acquisition. AA was involved in the design of the experiments, analysis and interpretation of data. SK carried out the synthesis of the GFC7 nanocomplex. SF was involved in analysis and interpretation of data. ZM prepared the manuscript. MHN contributed to the conception and design of the GFC7 nanocomplex. MS was involved in design of the study and contributed to its conception. All authors were involved in drafting the manuscript or revising it critically for important intellectual content. All authors read and approved the final manuscript.

\section{Acknowledgments}

This work was supported financially by the Stem Cell Biology Department of the Stem Cell Technology Research Center and the Department of Research and Development of Sodour Ahrar Shargh Company. The authors are grateful to Dr Vahahid Khoddami (University of Utah School of Medicine, Salt Lake City, Utah, USA), Dr Ahmad Karimi and Abdolreza Ardeshirylajimi (Stem Cell Technology Research Center, Tehran, Iran), and Ehsan Janzamin (Tarbiat Modares University, Tehran, Iran).

\section{Author details}

${ }^{1}$ Stem Cell Technology Research Center, Tehran, Iran. ${ }^{2}$ Department of Research and Development, Sodour Ahrar Shargh Company, Tehran, Iran. ${ }^{3}$ Department of Hematology, Faculty of Medical Sciences, Tarbiat Modares University, Tehran, Iran.

Received: 25 April 2015 Revised: 30 April 2015

Accepted: 28 October 2015 Published online: 23 November 2015

\section{References}

1. Xu X, Kratz K, Wang W, Li Z, Roch T, Jung F, et al. Cultivation and spontaneous differentiation of rat bone marrow-derived mesenchymal stem cells on polymeric surfaces. Clin Hemorheol Microcirc. 2013;55(1):143-56. doi:10.3233/CH-131698

2. Daley GQ, Scadden DT. Prospects for stem cell-based therapy. Cell. 2008; 132(4):544-8. doi:10.1016/j.cell.2008.02.009.

3. Orza A, Soritau O, Olenic L, Diudea M, Florea A, Rus Ciuca D, et al. Electrically conductive gold-coated collagen nanofibers for placentalderived mesenchymal stem cells enhanced differentiation and proliferation. ACS Nano. 2011;5(6):4490-503. doi:10.1021/nn1035312.

4. Liu D, Yi C, Zhang D, Zhang J, Yang M. Inhibition of proliferation and differentiation of mesenchymal stem cells by carboxylated carbon nanotubes. ACS Nano. 2010:4(4):2185-95. doi:10.1021/nn901479w.

5. Yazdani SO, Hafizi M, Zali AR, Atashi A, Ashrafi F, Seddighi AS, et al. Safety and possible outcome assessment of autologous Schwann cell and bone marrow mesenchymal stromal cell co-transplantation for treatment of patients with chronic spinal cord injury. Cytotherapy. 2013;15(7):782-91. doi:10.1016/j.jcyt.2013.03.012.

6. Undale AH, Westendorf JJ, Yaszemski MJ, Khosla S. Mesenchymal stem cells for bone repair and metabolic bone diseases. Mayo Clin Proc. 2009;84(10):893-902. doi:10.1016/50025-6196(11)60506-5.

7. Liu XB, Jiang J, Gui C, Hu XY, Xiang MX, Wang JA. Angiopoietin-1 protects mesenchymal stem cells against serum deprivation and hypoxia-induced apoptosis through the PI3K/Akt pathway. Acta Pharmacol Sin. 2008; 29(7):815-22. doi:10.1111/j.1745-7254.2008.00811.x.

8. Mohammadzadeh M, Halabian R, Gharehbaghian A, Amirizadeh N, Jahanian-Najafabadi A, Roushandeh AM, et al. Nrf-2 overexpression in mesenchymal stem cells reduces oxidative stress-induced apoptosis and cytotoxicity. Cell Stress Chaperones. 2012;17(5):553-65. doi:10.1007/s12192-012-0331-9.

9. Mohyeddin Bonab M, Yazdanbakhsh S, Lotfi J, Alimoghaddom K, Talebian F, Hooshmand F, et al. Does mesenchymal stem cell therapy help multiple sclerosis patients? Report of a pilot study. Iran J Immunol. 2007;4(1):50-7.

10. Venkataramana NK, Kumar SK, Balaraju S, Radhakrishnan RC, Bansal A, Dixit A, et al. Open-labeled study of unilateral autologous bone-marrow-derived mesenchymal stem cell transplantation in Parkinson's disease. Transl Res. 2010;155(2):62-70. doi:10.1016/j.trsl.2009.07.006.

11. Sun Q, Zhang Z, Sun Z. The potential and challenges of using stem cells for cardiovascular repair and regeneration. Genes Dis. 2014;1(1):113-9. doi:10. 1016/j.gendis.2014.07.003.

12. Zhang D, Li Y, Zhu T, Zhang F, Yang Z, Miao D. Zinc supplementation results in improved therapeutic potential of bone marrow-derived mesenchymal stromal cells in a mouse ischemic limb model. Cytotherapy. 2011;13(2):156-64. doi:10.3109/14653249.2010.512633.

13. Bara JJ, Richards RG, Alini M, Stoddart MJ. Bone marrow-derived mesenchymal stem cells change phenotype following in vitro culture: implications for basic research and the clinic. Stem Cells. 2014;32(7):1713-23. doi:10.1002/stem.1649.

14. Arora P, Sindhu A, Dilbaghi N, Chaudhury A, Rajakumar G, Rahuman AA. Nano-regenerative medicine towards clinical outcome of stem cell and tissue engineering in humans. J Cell Mol Med. 2012;16(9):1991-2000. doi:10. 1111/j.1582-4934.2012.01534.x.

15. Nazaran MH. Chelate compounds. Google Patents; 2012. Publication number: US20120100372 A1, Publication type: Application, Application number: US 12/910,799. http://www.google.com/patents/US20120100372.

16. Fakharzadeh S, Kalanaky S, Hafizi M, Goya MM, Masoumi Z, Namaki S, et al. The new nano-complex, Hep-c, improves the immunogenicity of the hepatitis B vaccine. Vaccine. 2013;31(22):2591-7. doi:10.1016/j.vaccine.2013. 03.030 .

17. Fakharzadeh S, Sahraian MA, Hafizi M, Kalanaky S, Masoumi Z, Mahdavi M, et al. The therapeutic effects of MSc1 nanocomplex, synthesized by nanochelating technology, on experimental autoimmune encephalomyelitic C57/BL6 mice. Int J Nanomedicine. 2014;9:3841-53. doi:10.2147/IJN.S64630.

18. Chen YC, Hsiao JK, Liu HM, Lai IY, Yao M, Hsu SC, et al. The inhibitory effect of superparamagnetic iron oxide nanoparticle (Ferucarbotran) on osteogenic differentiation and its signaling mechanism in human mesenchymal stem cells. Toxicol Appl Pharmacol. 2010;245(2):272-9. doi:10.1016/j.taap.2010.03.011

19. de Lima M, McMannis J, Gee A, Komanduri K, Couriel D, Andersson BS, et al. Transplantation of ex vivo expanded cord blood cells using the copper 
chelator tetraethylenepentamine: a phase I/II clinical trial. Bone Marrow Transplant. 2008;41(9):771-8. doi:10.1038/sj.bmt.1705979.

20. Peled T, Landau E, Prus E, Treves AJ, Nagler A, Fibach E. Cellular copper content modulates differentiation and self-renewal in cultures of cord blood-derived CD34+ cells. Br J Haematol. 2002;116(3):655-61.

21. Zhao ZL, Yang RY, Gu TM, Wang C, Sui ZF, Chang DQ. Migratory and chemoattractant responses of mesenchymal stem cells to oxidative stress injury of endothelial cell in vitro. Zhonghua Yi Xue Za Zhi. 2009;89(22):1577-81.

22. Alves $H$, Mentink A, Le B, van Blitterswijk CA, de Boer J. Effect of antioxidant supplementation on the total yield, oxidative stress levels, and multipotency of bone marrow-derived human mesenchymal stromal cells. Tissue Eng Part A. 2013;19(7-8):928-37. doi:10.1089/ten.TEA.2011.0700.

23. Si CL, Shen $T$, Jiang $Y Y, W u L, Y u$ GJ, Ren $X D$, et al. Antioxidant properties and neuroprotective effects of isocampneoside II on hydrogen peroxideinduced oxidative injury in PC12 cells. Food Chem Toxicol. 2013;59:145-52. doi:10.1016/j.fct.2013.05.051

24. Gharibi B, Hughes FJ. Effects of medium supplements on proliferation, differentiation potential, and in vitro expansion of mesenchymal stem cells. Stem Cells Transl Med. 2012;1(11):771-82. doi:10.5966/sctm.2010-0031.

25. Hafizi M, Bakhshandeh B, Soleimani M, Atashi A. Exploring the enkephalinergic differentiation potential in adult stem cells for cell therapy and drug screening implications. In Vitro Cell Dev Biol Anim. 2012;48(9):562-9. doi:10.1007/s11626-012-9546-4.

26. Zarif MN, Soleimani M, Abolghasemi H, Amirizade N, Arefian E, Rahimian A. Megakaryocytic differentiation of CD133+ hematopoietic stem cells by down-regulation of microRNA-10a. Hematology. 2013;18(2):93-100. doi:10.1179/1607845412Y.0000000047.

27. Bressan E, Carraro A, Ferroni L, Gardin C, Sbricoli L, Guazzo R, et al. Nanotechnology to drive stem cell commitment. Nanomedicine (Lond). 2013;8(3):469-86. doi:10.2217/nnm.13.12.

28. Stanko P, Kaiserova K, Altanerova V, Altaner C. Comparison of human mesenchymal stem cells derived from dental pulp, bone marrow, adipose tissue, and umbilical cord tissue by gene expression. Biomed Pap Med Fac Univ Palacky Olomouc Czech Repub. 2014;158(3):373-7. doi:10.5507/bp.2013.078.

29. Solanki A, Kim JD, Lee KB. Nanotechnology for regenerative medicine: nanomaterials for stem cell imaging. Nanomedicine (Lond). 2008;3(4):567-78. doi:10.2217/17435889.3.4.567.

30. Gowda R, Jones NR, Banerjee S, Robertson GP. Use of nanotechnology to develop multi-drug inhibitors for cancer therapy. J Nanomed Nanotechnol. 2013;4(6):pii:184. doi:10.4172/2157-7439.1000184.

31. Oh S, Brammer KS, Li YS, Teng D, Engler AJ, Chien S, et al. Stem cell fate dictated solely by altered nanotube dimension. Proc Natl Acad Sci U S A. 2009;106(7):2130-5. doi:10.1073/pnas.0813200106.

32. Sharma A, Madhunapantula SV, Robertson GP. Toxicological considerations when creating nanoparticle-based drugs and drug delivery systems. Expert Opin Drug Metab Toxicol. 2012;8(1):47-69. doi:10.1517/17425255.2012.637916.

33. Maghsoudi A, Fakharzadeh S, Hafizi M, Abbasi M, Kohram F, Sardab S, et al. Neuroprotective effects of three different sizes nanochelating based nano complexes in MPP(+) induced neurotoxicity. Apoptosis. 2015;20(3):298-309. doi:10.1007/s10495-014-1069-x.

34. Richardson DR, Kalinowski DS, Lau S, Jansson PJ, Lovejoy DB. Cancer cell iron metabolism and the development of potent iron chelators as anti-tumour agents. Biochim Biophys Acta. 2009;1790(7):702-17. doi:10.1016/j.bbagen.2008.04.003.

35. Huang DM, Hsiao JK, Chen YC, Chien LY, Yao M, Chen YK, et al. The promotion of human mesenchymal stem cell proliferation by superparamagnetic iron oxide nanoparticles. Biomaterials. 2009;30(22):3645-51. doi:10.1016/j.biomaterials.2009.03.032

36. Peled T, Glukhman E, Hasson N, Adi S, Assor H, Yudin D, et al. Chelatable cellular copper modulates differentiation and self-renewal of cord bloodderived hematopoietic progenitor cells. Exp Hematol. 2005;33(10):1092-100. doi:10.1016/j.exphem.2005.06.015.

37. Rodriguez JP, Rios S, Gonzalez M. Modulation of the proliferation and differentiation of human mesenchymal stem cells by copper. J Cell Biochem. 2002;85(1):92-100.

38. Choudhery MS, Badowski M, Muise A, Pierce J, Harris DT. Donor age negatively impacts adipose tissue-derived mesenchymal stem cell expansion and differentiation. J Transl Med. 2014;12:8. doi:10.1186/1479-5876-12-8.

39. Diederichs $S$, Tuan RS. Functional comparison of human-induced pluripotent stem cell-derived mesenchymal cells and bone marrow-derived mesenchymal stromal cells from the same donor. Stem Cells Dev. 2014; 23(14):1594-610. doi:10.1089/scd.2013.0477.

40. Schaffler A, Buchler C. Concise review: adipose tissue-derived stromal cells-basic and clinical implications for novel cell-based therapies. Stem Cells. 2007;25(4):818-27. doi:10.1634/stemcells.2006-0589.

41. Aguiar A, Kuligovski C, Costa M, Stimamiglio M, Rebelatto C, Senegaglia A et al. Alkaline phosphatase-positive cells isolated from human hearts have mesenchymal stem cell characteristics. Stem Cell Discovery. 2011;1:71-80. doi:10.4236/scd.2011.13008.

42. Etheridge ML, Campbell SA, Erdman AG, Haynes CL, Wolf SM, McCullough J. The big picture on nanomedicine: the state of investigational and approved nanomedicine products. Nanomedicine. 2013;9(1):1-14. doi:10.1016/j.nano. 2012.05.013

43. Xu XL, Wu LC, Du F, Davis A, Peyton M, Tomizawa Y, et al. Inactivation of human SRBC, located within the 11p15.5-p15.4 tumor suppressor region, in breast and lung cancers. Cancer Res. 2001;61(21):7943-9.

44. Royster RL, Butterworth JF, Prough DS, Johnston WE, Thomas JL, Hogan PE, et al. Preoperative and intraoperative predictors of inotropic support and long-term outcome in patients having coronary artery bypass grafting. Anesth Analg. 1991;72(6):729-36.

45. Rahman I. Antioxidant therapeutic advances in COPD. Ther Adv Respir Dis. 2008:2(6):351-74. doi:10.1177/1753465808098224.

46. Nishihira S, Okubo N, Takahashi N, Ishisaki A, Sugiyama Y, Chosa N. High-cell density-induced VCAM1 expression inhibits the migratory ability of mesenchymal stem cells. Cell Biol Int. 2011;35(5):475-81. doi:10.1042/ CBI20100372.

47. Yang JX, Zhang N, Wang HW, Gao P, Yang QP, Wen QP. CXCR4 receptor overexpression in mesenchymal stem cells facilitates treatment of acute lung injury in rats. J Biol Chem. 2015;290(4):1994-2006. doi:10.1074/jbc. M114.605063.

48. Chamberlain G, Fox J, Ashton B, Middleton J. Concise review: mesenchymal stem cells: their phenotype, differentiation capacity, immunological features, and potential for homing. Stem Cells. 2007;25(11):2739-49. doi:10.1634/ stemcells.2007-0197.

49. Dighe PA, Viswanathan P, Mruthunjaya AK, Seetharam RN. Effect of bFGF on HLA-DR expression of human bone marrow-derived mesenchymal stem cells. J Stem Cells. 2013;8(1):43-57.

50. Shafiee A, Kabiri M, Ahmadbeigi N, Yazdani SO, Mojtahed M, Amanpour S, et al. Nasal septum-derived multipotent progenitors: a potent source for stem cell-based regenerative medicine. Stem Cells Dev. 2011;20(12):2077-91. doi:10.1089/scd.2010.0420

51. Liu DD, Zhang JC, Zhang Q, Wang SX, Yang MS. TGF-beta/BMP signaling pathway is involved in cerium-promoted osteogenic differentiation of mesenchymal stem cells. J Cell Biochem. 2013;114(5):1105-14. doi:10.1002/ jcb. 24451

52. Liu X, Ming Y, Chen L, Peng L, Ye Q, Zheng S, et al. TNF-a and G-CSF induce CD62L and CD106 expressions on rat bone marrow-derived MSCs. Asian Biomed. 2012;6(3):453-8.

\section{Submit your next manuscript to BioMed Central and take full advantage of:}

- Convenient online submission

- Thorough peer review

- No space constraints or color figure charges

- Immediate publication on acceptance

- Inclusion in PubMed, CAS, Scopus and Google Scholar

- Research which is freely available for redistribution 